\title{
CHALLENGES TO CHINA'S NEW STOCK MARKET FOR SMALL AND MEDIUM-SIZE ENTERPRISES: TRADING PRICE FALLS BELOW THE IPO PRICE
}

\author{
Haifeng GUO ${ }^{a}$, Tienan WANG ${ }^{b}$, Yijun LI $^{\mathrm{c}}$, Hung-Gay FUNG \\ ${ }^{a}$ Department of Applied Economics, School of Management, \\ Harbin Institute of Technology, China \\ ${ }^{b}$ Department of Business Administration, School of Management, Harbin Institute of Technology, China \\ 'Department of Management Science and Engineering, School of Management, \\ Harbin Institute of Technology, China \\ ${ }^{d}$ College of Business Administration, University of Missouri-St. Louis, USA
}

Received 09 September 2012; accepted 20 July 2013

\begin{abstract}
This study discusses the development of the Growth Enterprise Board (GEB), a part of the Shenzhen Stock Exchange (SZSE), which allows small and medium-size enterprises (SMEs) to raise capital on favourable terms by issuing shares in China. We use all initial public offerings (IPOs) in the GEB market to model the probability of the trading price for new issues that will fall below their IPO price from October 2009 to December 31, 2011. Three probability models (logit, probit and scobit models) are used. The results show that four important factors explain the probability of trading price falling below their IPO price. A high first-day turnover ratio, a small price update, an optimistic stock market, and high average initial returns of other firms prior to an IPO issue all reduce the risk that the trading price will fall below the IPO price. The stock market returns have a non-linear significant effect on that probability. Our results are useful for regulators, underwriters, and issuers in the development of the GEB market.
\end{abstract}

Keywords: growth enterprise board, IPO, Chinese stock market, probability model.

Reference to this paper should be made as follows: Guo, H.; Wang, T.; Li, Y.; Fung, H.-G. 2013. Challenges to China's new stock market for small and medium-size enterprises: trading price falls below the IPO price, Technological and Economic Development of Economy 19(Supplement 1): S409-S424.

JEL Classification: C51, G24, G28.

Corresponding author Haifeng Guo

E-mail: haifengguo@hit.edu.cn 


\section{Introduction}

Since the economic reforms in China initiated in 1979 began to transform its socialist economy into a market-oriented economy, the country has experienced economic growth of about $9 \%$ on average and its economy has become the second-largest in the world after that of the United States. Economic growth depends critically on the performance of small and medium-size enterprises (SMEs), which provide sustainable employment and thus help fuel growth for the entire economy but will need the government's assistance if they are to continue to grow (Fung et al. 2006; Pilinkus 2010; Liu et al. 2011).

Milana and $\mathrm{Wu}$ (2012) propose that the Chinese economy is undergoing changes in a high growth speed, which can be a success story as a developing country; however, they indicate that the Chinese enterprises still meet many problems and challenges, especially in capital financing. The Chinese government has implemented various policies to help make raising capital easier for SMEs (Fung et al. 2007). One new development is its consideration of launching a new equity exchange in Beijing to allow investors to trade shares of unlisted companies through a market-maker system (Li 2012). More recently, China has been considering the expansion of a trial pilot program under which certain unlisted companies in Beijing, Shanghai, and Wuhan are allowed to sell shares on an over-the-counter (OTC) trading platform in an effort to facilitate access to funding for small business. Such an expansion would be the first step in a plan to establish an OTC market (Li, Hong 2012).

The policy now in effect that helps SMEs raise capital effectively depends critically on a formal market in which they can list their shares on a stock exchange. To that end, a small and medium-size enterprise block (SMEB) was formed within the main board of the Shenzhen Stock Exchange (SZSE) in 2004. The problem with this structure is that companies listed on the SMEB have to satisfy the same listing requirements as all other companies listed on the main board. The requirements of higher profitability and larger size are particularly difficult for SMEs to satisfy, which makes many SMEs face challenges in raising equity capital through this board (Guariglia et al. 2011).

In light of this problem, the SZSE formally launched a new market called the Growth Enterprise Board (GEB) in October 2009 as part of efforts to facilitate easier access to financing opportunities for SMEs. The goal is also to relax the stringent listing requirements imposed by the SMEB. The GEB is a NASDAQ-like board, which is separate from the main board of the SZSE and the Shanghai Stock Exchange (SHSE). This board helps innovative and rapidly growing firms raise capital more easily through IPOs. Many successful companies, such as Apple and Microsoft, initially raised capital on the NASDAQ in the United States before becoming large and well-known enterprises. The GEB, like the NASDAQ, imposes lower listing requirements for these SMEs making an IPO as compared to those companies that are qualified to be listed on the main board (Guo, Fung 2011). The GEB represents a milestone development in China's financial market, and the success of this market provides valuable lessons for other emerging markets. Although the Chinese GEB market has developed for about three years, there are many problems have to be addressed in this market, such as pricing problem, investor enthusiasm, and issuing and listing systems, etc. Zhao and Sun (2012) has tested the pre-IPO earnings management and the post-IPO performance under the background of venture capital investment, 
and they find that there are a big portion of enterprises who are invested by venture capital and then venture capital plays an important role in GEB market, including IPO pricing and post-IPO performance. However, there is lack of research on how the board's development is and the risk of IPOs, although there are an agreement that the investing risk in GEB is higher than in the main board (Dong, Pandey 2012).

This paper examines the development of the GEB market, focusing specifically on its overpricing problem. The GEB market is a particularly important financing mechanism for SMEs to grow. Many big Chinese banks primarily focus their lending policies on state-owned enterprises, which are government protected, and they are not willing to lend to SMEs, which entail greater risk. The GEB has several unique characteristics that distinguish it from the main board of the Shenzhen and Shanghai stock markets.

This paper discusses the stock market development and overpricing of the GEB and initial public offerings (IPOs) of Chinese firms, which might provide useful lessons for other emerging markets. Traditionally, underpricing of IPOS (i.e. the trading price above the IPO price) is a predominant issue in China (Guo et al. 2011). In recent years, overpricing of the IPOs becomes a serious concern to the Chinese securities regulator, China Securities Regulatory Commission (CSRC), which has taken steps to mitigate the overpricing issue (see Business Week, June 25-July 1, 2012, 43-44.). Overpricing may adversely affect the long-term development of the IPOs market. After April, 2012, if the price-to-earnings ratio of an IPO is expected to be $25 \%$ higher than that of publicly traded companies in the same industry, the issuing firm will have to disclose the factors behind the pricing decision. In addition, CSRC will now invite individuals and institutional investors to advise on the IPO pricing, reducing the likelihood of overpricing. Our paper examines factors that can explain the overpricing. Thus, the results of the paper provide suggestions and guidelines for Chinese policymakers, underwriters, and issuing firms.

The rest of the paper is organized as follows. Section 1 describes the GEB's characteristics during the IPO process, finding high uncertainty and pricing problems in that market's IPOs. Section 2 employs logit, probit and scobit regression methods to detect which factors affect the pricing performance of those IPOs. Section 3 makes an empirical study and discusses the results. The final section draws the conclusions.

\section{Characteristics of the GEB}

Since the two exchanges (SZSE and SHSE) were established in 1990, IPOs in China have been characterized by an extremely high level of underpricing (Chan et al. 2004; Chen et al. 2004; Chi, Padgett 2005; Chiou et al. 2010; Guo et al. 2011), although many countries also have some degree of underpricing in their IPOs (Loughran, Ritter 2004). Especially in the early years of market development in China, IPOs historically attracted a large number of optimistic investors who were fascinated by high positive initial-day returns.

Figure 1 lists the total number of IPOs each year in China and their corresponding initial-day returns. The figure reveals that the Chinese IPO market has been subject to cyclical issuing periods with ups and downs in the past twenty years, during which the market was hot in 1992-1993, 1996-2000, and 2010-2011, as seen in Guo et al. (2010). Initial-day returns were extremely high in the early years (i.e. the returns were more than $400 \%$ ) and declined 


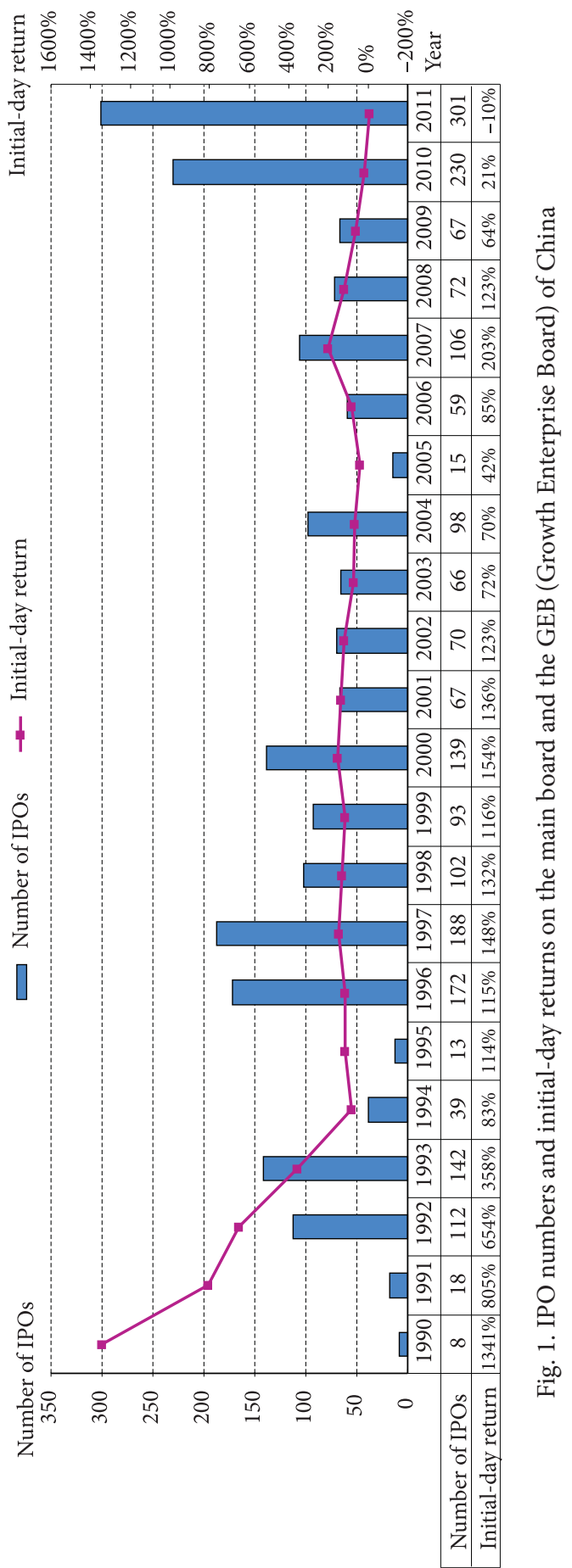


after 1994. From 1995 to 2002, initial-day returns generally stabilized at about 100-150\%. From 2003 to 2006, initial-day returns fell below 100\% and then in 2007 suddenly increased to $203.02 \%$. During the period from 2007 to 2009, the IPOs in China were quite normal. After 2009, the returns decreased, reaching a $9.59 \%$ in 2011, because of reforms in the IPO market, including the elimination of the offering price supervision system and establishment of the GEB. After the 2009 reform, the number of IPOs listed increased and the IPOs' initial-day returns fell. From the data and the results, we can find that the reform in 2009 has brought significant changes to the Chinese stock market, especially on the initial public offerings market (Zhang et al. 2012). Before the reform, the CSRC is thought to be one of the strict regulators to supervise enterprises which plan to issue public offerings. However, after this reform, the CSRC allocates issuers and underwriters more room to decide their offerings' price. One of the policies related to pricing is that the CSRC do not regulate the offering price of an IPO during the offering process, which was called "window supervising policy". After the elimination of this policy, the offering prices are much easier to be monitored by underwriters and issuers. Thus, they are more willing to set a high offering price to collect more initial proceeds, likely leading to the current phenomenon that the trade prices fall below the offering prices.

As seen in Figure 2, the IPOs' average initial-day return in the GEB market was $84 \%$ in 2009 and then decreased to $37.26 \%$ in 2010 and $22.78 \%$ in 2011 . Comparing the GEB and the main board for 2009-2011, we find that initial-day returns are generally higher in the GEB market, which act as a lure for investors.

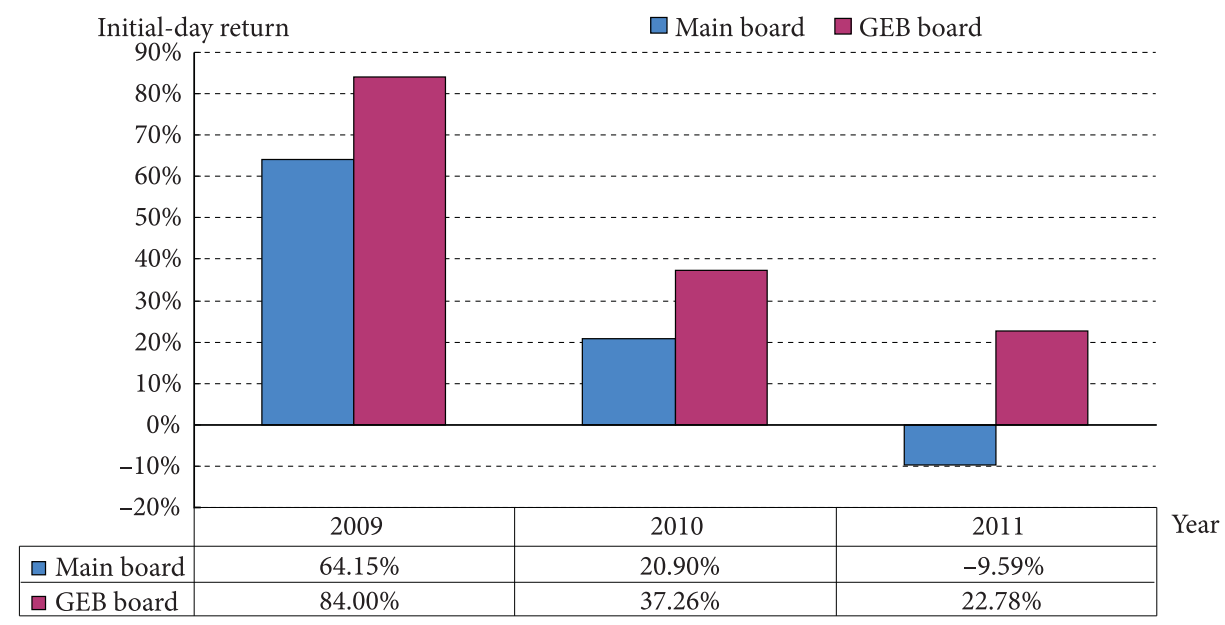

Fig. 2. Initial-day returns of the GEB (Growth Enterprise Board) and main board of China

In light of the rapid development of the GEB market, one puzzling issue that policymakers and investors confront is that the pricing of the relatively new market appears to be volatile. Figure 3 shows the volatility of first-day price performance, which is the difference between the highest price and the lowest price and then normalized by the offering price (i.e. volatility $=$ (highest price - lowest price)/offering price). The volatility in 2009 is extremely high, indicating that the trading price intervals are very large. This phenomenon is consistent with the reform of Chinese IPO market. 


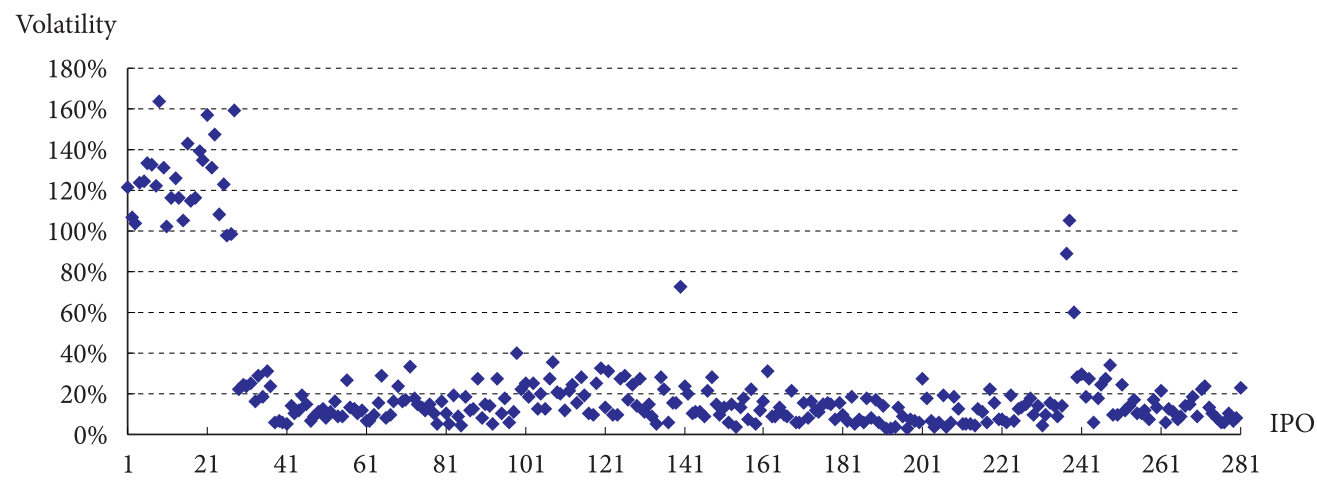

Fig. 3. Volatility of initial public offerings in the GEB

One interesting thing should be noted here. Rather than finding substantial underpricing for IPOs, we observe substantial overpricing. The trading prices of many stocks fall below their initial offering price even on the first day after listing. Now, Chinese investors who became accustomed to buying those underpriced IPOs and benefiting from the price jump up on the first day of trading will have to face the reality of higher risk that the trading price will fall.

Since the 2009 IPO reform, this phenomenon has become more severe and thus has attracted more attention. It has even become an important issue for policymakers, who are concerned that investor sentiment will turn negative and harm the future development and growth of the GEB. This study examines that rationale behind why so many new issues are falling below their IPO price and how to minimize the price volatility of GEB market. Our results provide insights that shed light on developing a better and healthier GEB market.

To explain IPO price behaviour better, we sort firms whose trading price fell below their offering price according to listing date. Table 1 reports that 37 IPOs had trading prices that fell below their offering prices on the first listing date, about $13 \%$ of IPOs, and 62 IPOs falling within 30 days ( excluding those falling on the first listing day), about $22 \%$ of IPOs. During the 180 days of our observation period, $55 \%$ of IPOs saw their price fall. Such a high proportion indicates the high degree of pricing error.

Table 1. The duration (days) of IPOs from listing to the break date that the trading price falls below its offering price

\begin{tabular}{clccccccc}
\hline Listing Date & $\begin{array}{l}\text { Period from list- } \\
\text { ing to break date }\end{array}$ & $\mathbf{1}$ & $\mathbf{( 1 , 3 0 ]}$ & $\mathbf{( 3 0 , 6 0 ]}$ & $\mathbf{( 6 0 , 1 8 0 ]}$ & $\begin{array}{c}\text { Not } \\
\text { Failed }\end{array}$ & Total \\
\hline \multirow{2}{*}{ Quarter 4, 2009 } & IPO number & 0 & 0 & 0 & 2 & 34 & 36 \\
\cline { 2 - 8 } & percentage & $0 \%$ & $0 \%$ & $0 \%$ & $6 \%$ & $94 \%$ & $100 \%$ \\
\hline \multirow{2}{*}{ Quarter 1, 2010 } & IPO number & 0 & 8 & 3 & 4 & 14 & 29 \\
\cline { 2 - 8 } & percentage & $0 \%$ & $28 \%$ & $10 \%$ & $14 \%$ & $48 \%$ & $100 \%$ \\
\hline \multirow{2}{*}{ Quarter 2, 2010 } & IPO number & 4 & 13 & 1 & 0 & 7 & 25 \\
\cline { 2 - 8 } & percentage & $16 \%$ & $52 \%$ & $4 \%$ & $0 \%$ & $28 \%$ & $100 \%$ \\
\hline \multirow{2}{*}{ Quarter 3, 2010 } & IPO number & 1 & 1 & 2 & 2 & 27 & 33 \\
\cline { 2 - 8 } & percentage & $3 \%$ & $3 \%$ & $6 \%$ & $6 \%$ & $82 \%$ & $100 \%$ \\
\hline
\end{tabular}


Continued Table 1

\begin{tabular}{clccccccc}
\hline \multirow{2}{*}{ Listing Date } & $\begin{array}{l}\text { Period from list- } \\
\text { ing to break date }\end{array}$ & $\mathbf{1}$ & $\mathbf{( 1 , 3 0 ]}$ & $\mathbf{( 3 0 , 6 0 ]}$ & $\mathbf{( 6 0 , 1 8 0 ]}$ & $\begin{array}{c}\text { Not } \\
\text { Failed }\end{array}$ & Total \\
\hline \multirow{2}{*}{ Quarter 4, 2010 } & IPO number & 0 & 6 & 2 & 10 & 12 & 30 \\
\cline { 2 - 8 } & percentage & $0 \%$ & $20 \%$ & $7 \%$ & $33 \%$ & $40 \%$ & $100 \%$ \\
\hline \multirow{2}{*}{ Quarter 1, 2011 } & IPO number & 12 & 15 & 0 & 12 & 4 & 43 \\
\cline { 2 - 9 } & percentage & $28 \%$ & $35 \%$ & $0 \%$ & $28 \%$ & $9 \%$ & $100 \%$ \\
\hline \multirow{2}{*}{ Quarter 2, 2011 } & IPO number & 16 & 9 & 2 & 2 & 11 & 40 \\
\cline { 2 - 9 } & percentage & $40 \%$ & $22 \%$ & $5 \%$ & $5 \%$ & $28 \%$ & $100 \%$ \\
\hline \multirow{2}{*}{ Quarter 3, 2011 } & IPO number & 1 & 7 & 3 & 6 & 14 & 31 \\
\cline { 2 - 9 } & percentage & $3 \%$ & $23 \%$ & $10 \%$ & $19 \%$ & $45 \%$ & $100 \%$ \\
\hline \multirow{2}{*}{ Total } & IPO number & 3 & 3 & 3 & 1 & 4 & 14 \\
\cline { 2 - 9 } & percentage & $21 \%$ & $21 \%$ & $21 \%$ & $7 \%$ & $30 \%$ & $100 \%$ \\
\hline
\end{tabular}

Note: If an IPO's trading price falls below its offering price on its first listing date, we mark this period as 1 day. We summarize IPOs into 9 quarter groups according to its listing date.

China's securities regulator CSRC, has become concerned about the overpricing, pushing for a more market-based system. It thus requires companies to disclose more essential information to the public so that investors can evaluate deals for themselves. The intention is to force all the parties involved in a company's listing, such as underwriters, lawyers, and auditors, to take more responsibility for the quality of IPOs (Zandi et al. 2012). As the burden of information disclosure falls on the issuing firms, such costs will cause them to slow down their application for an IPO, leading to a reduction in the backlog of IPO candidates (Wong, Govindaraju 2012).

At the same time, Chinese regulators also need to understand which factors lead to overpricing. According to a recent Wall Street Journal report, among companies that have applied for IPOs for the first time by the regulators, more than 500 firms are already listed, while some of them have been waiting more than three years for listing approval (Li, McMahon 2012). An interesting question remains as to whether the Chinese government should speed up the approval process or to slow it down at this time of a down market.

\section{Methodology and data}

\subsection{Data}

The GEB IPO data come primarily from the Beijing Juyuan RESSET Financial Research Database (Available at: www.resset.cn/cn/about/about_resset.jsp). Data from each company's prospectus and listing document were collected, including the GEB issuing process for IPOs and each IPO's price. Our sample includes 281 GEB IPOs issued since the initiation of the GEB market, that is, from October 2009 to December 31, 2011. 
Our observation period is 180 days, during which we see whether a new issue falls below its IPO price. We found that a total of 154 , almost half the sample, saw their price fall below the initially offered price within that time frame.

\subsection{Probability models}

In this study, we assume that the probability of trading prices for new issues falling below the offering price behaves as a linear function of explanatory variables, $X$, as follows:

$$
\operatorname{Pr}\left[Y_{j}=1 / X\right]=\beta X
$$

where: $\beta$ is $1 \times n$ vector of coefficients and $X$ is an $n \times 1$ vector of the independent variables. Equation (1) represents a linear model that can be estimated by a regression method. In this study, we use three models to estimate Equation (1): the logistic regression model, the probit regression model and the scobit model. In the logit model, the dependent variable takes the following form:

$$
\operatorname{Pr}\left[Y_{j}=1 / X_{1 j}, \ldots X_{k j}\right]=\frac{1}{1+\exp \left(-\beta_{1}^{0} X_{1 j}-\ldots-\beta_{k}^{0} X_{k j}\right)}=\frac{1}{1+\exp \left(-\sum_{i=1}^{k} \beta_{i}^{0} X_{i j}\right)} .
$$

The log-likelihood function of the model is:

$$
\operatorname{Ln}\left(\operatorname{Ln}\left(\beta_{1}, \ldots, \beta_{k}\right)\right)=-\sum_{j=1}^{n}\left(1-Y_{j}\right) \sum_{i=1}^{k} \beta_{i} X_{i j}-\sum_{j=1}^{n} \ln \left(1+\exp \left(-\sum_{i=1}^{k} \beta_{i} X_{i j}\right)\right)
$$

We can use the maximum likelihood method to estimate the function. The maximum likelihood estimators $\hat{\beta}_{1}, \ldots, \hat{\beta}_{k}$ are obtained by maximizing the likelihood function, $\operatorname{Ln}\left(\operatorname{Ln}\left(\beta_{1}, \ldots, \beta_{k}\right)\right)$ as follows:

$$
\operatorname{Ln}\left(\operatorname{Ln}\left(\hat{\beta}_{1}, \ldots, \hat{\beta}_{k}\right)\right)=\max _{\beta_{1}, \ldots, \beta_{k}} \operatorname{Ln}\left(\operatorname{Ln}\left(\beta_{1}, \ldots, \beta_{k}\right)\right) .
$$

In the function above, if $\beta_{0}>0$, then $\operatorname{Pr}\left[Y_{j}=1 / X_{j}\right]=F\left(\alpha_{0}+\beta_{0} X_{j}\right)$ is an increasing function of $X_{j}$ :

$$
\frac{d \operatorname{Pr}\left[Y_{j}=1 / X_{j}\right]}{d X_{j}}=\beta_{0} F^{\prime}\left(\alpha_{0}+\beta_{0} X_{j}\right)
$$

where $F^{\prime}$ is the first derivative, and:

$$
\begin{aligned}
& F^{\prime}(x)=\frac{\exp (-x)}{(1+\exp (-x))^{2}}=\frac{1+\exp (-x)}{(1+\exp (-x))^{2}}-\frac{1}{(1+\exp (-x))^{2}}= \\
& \frac{1}{(1+\exp (-x))}-\frac{1}{(1+\exp (-x))^{2}}=F(x)-F(x)^{2}=F(x)(1-F(x)) .
\end{aligned}
$$

The marginal effect of $X_{j}$ on $\operatorname{Pr}\left[Y_{j}=1 / X_{j}\right]$ depends on $X_{j}$ :

$$
\frac{d \operatorname{Pr}\left[Y_{j}=1 / X_{j}\right]}{d X_{j}}=\beta_{0} F\left(\alpha_{0}+\beta_{0} X_{j}\right)\left(1-F\left(\alpha_{0}+\beta_{0} X_{j}\right)\right) \text {. }
$$


Second, the probit regression model is quite similar to the logit model. However, in the probit model, a different structure of the probability function is assumed as follows:

$$
\operatorname{Pr}\left[Y_{j}=1 / X_{1 j}, \ldots X_{k j}\right]=\Phi\left(X_{j}^{\prime} \beta\right) .
$$

There is an auxiliary random variable:

$$
Y^{*}=X_{j}^{\prime} \beta+\varepsilon,
$$

where: $\varepsilon$ (noise term) $\sim N(0,1)$, yielding:

$$
Y=1_{\left\{Y^{*}>0\right\}}=\left\{\begin{array}{l}
1 \text { if } Y^{*}>0, \text { i.e. }-\varepsilon<X_{j}^{\prime} \beta, . \\
0 \text { otherwise. }
\end{array}\right.
$$

Both the logit and the probit regression models are estimated by the maximum likelihood method. Consequently, the goodness of fit test and related inferential statistics are based on the log likelihood and chi-square test statistics. Both logit and probit models have been widely used in the literature. The two models assume that firms with a $50 \%$ probability that their price will fall below the IPO price are most sensitive to changes in the independent variables. That is, a one-unit change in $X$ will have a greater effect on firms with a $50 \%$ probability of the price that does not fall below the IPO prices than it will have on firms with a $30 \%$ or $70 \%$ probability.

Nagler (1994) discusses that there exists a kind of situation when the distribution is not symmetrical as assumed in the logit and probit models. For example, an IPO firm with a 40\% probability of trading price fall below its IPO prices may be more affected by a one unit change in the independent variable than other firm which has a 50\% probability of falling below its offering price. If so, the distribution is "skewed" and is not symmetric around 50\%. Nagler (1994) proposes an estimation method to overcome this asymmetric assumption in the logit model, which is called scobit model (Nagler 1994). In order to make our estimation more robust, we use probit, logit and scobit models to detect the underlying reasons which might affect the hazard of falling risk. In our paper, we try to explain what reasons affect the falling risk of the offering prices. In order to investigate this problem, we set the falling risk as a $(0,1)$ dummy variable. We then use the three probability models to shed light on the problems. These models serve as a robustness check for the results to avoid biasness in one particular model.

In the three probability models, we use several explanatory variables that relate to firm attributes and market conditions for our analysis. These explanatory variables, which are well documented in the literature for pricing of IPOs, are discussed as follows.

\section{Firm attributes}

Five variables regarding a firm are included in our analysis. First, the turnover ratio refers to the trading frequency of a stock on its first trading day of the number of tradable A-shares. The more shares are traded on the first listing day, the more interest and demand investors have in this particular IPO, implying that this variable is negatively related to the risk of trading prices falling below the IPO price.

Second, the long-run performance of an IPO relates closely to price adjustment during the IPO process (Kutsuna et al. 2009). To compute the pricing adjustment, we follow the study of Lowry et al. (2010) and use the variable Price Update, which represents the percentage 
change from the original price as in the prospectus submitted to the CSRC to price at which the IPO is actually launched. Price Update is computed as Price Update $=\left(P_{i, 0-} P_{\text {original }}\right) / P_{\text {original }}$, where $P_{\text {original }}$ is the original price in the preliminary prospectus. Lowry et al. (2010) indicate that this variable represents a proxy for the learning that occurs during the registration period when the IPO is first marketed to investor, implying larger pricing errors. Substantial learning (that is, a higher absolute value of Price Update) is more likely for firms whose value is more uncertain. According to the background of Chinese stock market, we addressed the "window supervising policy" in Section 1. The policy was eliminated by CSRC in 2009. As a result, issuers and underwriters are able to set a high offering price to collect more money during offering process. The original price, which was later released by CSRC, appears to be very low. So the price update reflects valuable information as how much the offering price differs from the original price. This variable is expected to have a positive sign, implying a reduced probability that the market price will fall below the subscription price.

Third, we include the $P / E$ ratio, which is the subscription price over the earnings of the firm. In order to minimize the effect of the different industries, we use normalized $P / E$ ratio (i.e. the $\mathrm{P} / \mathrm{E}$ ratio is normalized by an average of $\mathrm{P} / \mathrm{E}$ ratios for all IPOs). We expect this variable to affect the probability negatively because a higher $P / E$ ratio implies a higher likelihood of overpricing.

Fourth, we compute a winning lottery ratio, which is the number of successful subscribers compared to the number of total valid subscribers (normalized by an average of all IPOs). This ratio reflects whether an IPO is in great demand. A bigger (smaller) ratio indicates lower (greater) demand for an IPO compared with the issue size (Chi, Padgett 2005). An IPO in great demand will have a better long-run price performance. This ratio is expected to have a positive sign on the probability of falling risk.

Fifth, we include an attribute about the underwriter of the issuing firm. The after-market performance is supposed to be related to the character of underwriters, who knows when to provide corresponding price support (Aggarwal 2000). Ellis et al. (2000) show a significant link between underwriters' trading profits and IPO underpricing while Lewellen (2006) indicates that large underwriters may be more willing to support overpriced IPOs to protect their reputation, because overpricing hurts an underwriter's reputation and decreases future underwriting revenue.

To examine whether the trading prices of new issues are related to underwriters, we classify underwriters in two groups according to their average market share (Megginson, Weiss 1991). The large underwriters are given a rank of 1. As in Megginson and Weiss (1991), if the issuing firm has more than one lead underwriter, the average of the lead underwriters' market share is used as the measure of quality. We expect the first-rank underwriters to be able to support prices, and thus there should be less risk that the trading price will fall below the initial offering price. A $(1,0)$ dummy variable equals 1 for an IPO that is underwritten by a first-rank underwriter and equals 0 otherwise.

\section{General market variables}

In this group of variables, we compute two variables that represent general market sentiment. First, we compute a proxy variable that represents the general sentiment of the IPO market. 
The average initial return for a stock is obtained by averaging initial returns of 30 prior IPOs before the issuing of that stock. This variable serves as a proxy for general market reactions to the IPO issues. Higher average initial returns imply more favourable reactions by market participants to the new offering, implying a negative effect on the probability that the market price will fall below the offering price. We can compute the initial-day return, $I R\left(I R_{i}=\right.$ $\left.\left(P_{i, 1 s t} / P_{i, 0}\right)-1\right)$, where $P_{i, 1 s t}$ is the closing price of stock $i$ on the first trading day and $P_{i, 0}$ is the offering price of stock $i$. IR indicates the degree to which investors are compensated for their risk relating to that particular stock during the IPO subscription (Derrien 2005). Average IR is computed by averaging the IR of prior 30 IPOs other than the forthcoming issuing firm. A high average $I R$ means that the IPO market is bullish. An average IR is expected to have a negative effect on the probability function of a forthcoming IPO.

Second, pessimistic market sentiment may negatively affect an IPO's trading price (Cornelli et al.2006) - that is, an IPO is more likely to have its trading price fall below its offering price if it is listed at a time of negative market sentiment. We measure general market sentiment by the stock market return $\left(S M R=\left(M_{i, F} / M_{i, 0}\right)-1\right)$ between an IPO's offering date and the time it falls below its offering price as a proxy for the market sentiment variable. $M_{i, F}$ is the SHSE A-share composite index when the stock $i$ falls below its offering price ${ }^{1} . M_{i, 0}$ is the SHSE A-share composite index on the stock $i$ 's offering day. Thus, $S M R$ is expected to have a negative effect on the likelihood that new issue will have its trading price fall below its offering price.

\section{Empirical analysis and results}

Table 2 presents the variables used in this study. The mean of the initial return is $30 \%$, which is sizable for one-day performance, while the average initial return is $35 \%$. The stock market return is negative, indicating that general market conditions are not favourable during our sample period.

Table 2. Descriptive statistics results

\begin{tabular}{lcccccc}
\hline \multicolumn{1}{c}{ Variables } & Mean & S.D. & Maximum & Minimum & Skewness & Kurtosis \\
\hline First day turnover ratio & $70.46 \%$ & $18.10 \%$ & $95.92 \%$ & $18.42 \%$ & 4.03 & -1.35 \\
Price update & 1.97 & 1.27 & 8.96 & -0.11 & 1.72 & 5.63 \\
Normalized P/E ratio & 0.99 & 0.35 & 2.50 & 0.34 & 0.03 & 1.83 \\
Normalized Winning & 1.03 & 1.36 & 16.51 & 0.26 & 6.93 & 65.88 \\
Lottery Ratio & & 0.09 & 0.16 & -0.27 & -0.23 & -0.32 \\
Stock Market Return & -0.04 & 0.21 & 1.04 & 0.04 & 0.78 & 0.92 \\
Average Initial Return & 0.35 & & & & &
\end{tabular}

Table 3 shows the correlation results for the variables. The initial return is related to other variables, particularly with the first-day turnover. It implies that a stock with a high first-day return will have high turnover during that day.

China offers a two-tiered share system of stocks trading. The A-share market of company shares traded is primarily offered to the Chinese citizens while the B-share system (traded in foreign currencies) is tailored to foreign investors or to local residents who have foreign currencies. 
Table 3. Correlation analysis results

\begin{tabular}{|c|c|c|c|c|c|c|c|c|}
\hline & & $\begin{array}{c}\text { First day } \\
\text { turnover } \\
\text { ratio }\end{array}$ & $\begin{array}{c}\text { Price } \\
\text { update }\end{array}$ & $\mathrm{P} / \mathrm{E}$ ratio & $\begin{array}{c}\text { Winning } \\
\text { lottery } \\
\text { ratio }\end{array}$ & $\begin{array}{c}\text { Dummy } \\
\text { (Under- } \\
\text { writer first } \\
\text { rank) }\end{array}$ & $\begin{array}{c}\text { Stock } \\
\text { market } \\
\text { return }\end{array}$ & $\begin{array}{c}\text { Average } \\
\text { initial } \\
\text { return }\end{array}$ \\
\hline \multirow{2}{*}{$\begin{array}{l}\text { First day } \\
\text { turnover } \\
\text { ratio }\end{array}$} & $\begin{array}{l}\text { Pearson } \\
\text { Coefficients }\end{array}$ & 1.00 & & & & & & \\
\hline & $\begin{array}{l}\text { Significance } \\
\text { level }\end{array}$ & & & & & & & \\
\hline \multirow{2}{*}{$\begin{array}{l}\text { Price } \\
\text { update }\end{array}$} & $\begin{array}{l}\text { Pearson } \\
\text { Coefficients } \\
\end{array}$ & -0.28 & 1.00 & & & & & \\
\hline & $\begin{array}{l}\text { Significance } \\
\text { level }\end{array}$ & 0.00 & & & & & & \\
\hline \multirow{2}{*}{$\mathrm{P} / \mathrm{E}$ ratio } & $\begin{array}{l}\text { Pearson } \\
\text { Coefficients }\end{array}$ & -0.20 & 0.50 & 1.00 & & & & \\
\hline & $\begin{array}{l}\text { Significance } \\
\text { level }\end{array}$ & 0.01 & 0.00 & & & & & \\
\hline \multirow{2}{*}{$\begin{array}{l}\text { Winning } \\
\text { lottery } \\
\text { ratio }\end{array}$} & $\begin{array}{l}\text { Pearson } \\
\text { Coefficients }\end{array}$ & -0.10 & 0.00 & -0.07 & 1.00 & & & \\
\hline & $\begin{array}{l}\text { Significance } \\
\text { level }\end{array}$ & 0.08 & 0.99 & 0.22 & & & & \\
\hline \multirow{2}{*}{$\begin{array}{l}\text { Dummy } \\
\text { (Under- } \\
\text { writer } \\
\text { first } \\
\text { rank) }\end{array}$} & $\begin{array}{l}\text { Pearson } \\
\text { Coefficients } \\
\end{array}$ & -0.05 & 0.15 & 0.05 & -0.06 & 1.00 & & \\
\hline & $\begin{array}{l}\text { Significance } \\
\text { level }\end{array}$ & 0.37 & 0.01 & 0.33 & 0.29 & & & \\
\hline \multirow{2}{*}{$\begin{array}{l}\text { Stock } \\
\text { market } \\
\text { return }\end{array}$} & $\begin{array}{l}\text { Pearson } \\
\text { Coefficients }\end{array}$ & -0.06 & -0.06 & 0.01 & 0.01 & -0.08 & 1.00 & \\
\hline & $\begin{array}{l}\text { Significance } \\
\text { level }\end{array}$ & 0.31 & 0.28 & 0.79 & 0.98 & 0.18 & & \\
\hline \multirow{2}{*}{$\begin{array}{l}\text { Average } \\
\text { initial } \\
\text { return }\end{array}$} & $\begin{array}{l}\text { Pearson } \\
\text { Coefficients }\end{array}$ & 0.05 & -0.14 & 0.29 & -0.31 & 0.11 & -0.14 & 1.00 \\
\hline & $\begin{array}{l}\text { Significance } \\
\text { level }\end{array}$ & 0.42 & 0.02 & 0.00 & 0.00 & 0.07 & 0.02 & \\
\hline
\end{tabular}

Table 4 presents the regression results for the probit, logit and scobit models. In the probit model, the coefficient of the initial-day turnover is negative and significant, a result consistent with our expectations, implying that a large initial-day turnover reduces the probability that the trading price of a new issue will fall below its offering price.

The Price Update variable has an effect on the probability of an IPO's trading price falling below the offering price, which indicates that pricing error may be triggered by a large price update.

The $S M R$ variable is negative $(-5.55)$ but highly significant $(p=0.00)$. The result implies that generally optimistic market sentiment will reduce the probability of that the trading price will fall below the offering price. This finding supports earlier results on China's IPO underpricing pattern as investors perceived new issues favourably when the China stock market started to bloom during the early stage of its development (Guo et al. 2010). 
Further analysis of market returns indicates that the market return squared has also a similar negative and significant effect on the probability that trading prices will fall below the offering price. Thus, the market return effect is found to be non-linear, but its negative effect increases at an accelerating rate. This further supports the importance of general market sentiment on the trading price behaviour of stock issues.

Average initial returns are found to be negative (-1.52) and statistically significant. This result suggests that large average initial returns of prior IPOs will push up the price of further new stock issues, reducing the probability of falling prices.

Other firm attributes such as $\mathrm{P} / \mathrm{E}$ ratio, winner lottery ratio and underwriter do not seem to affect the risk of falling prices. These results are somewhat surprising but point to the general conclusion that the prices of Chinese IPOs are greatly influenced by general market sentiment, but not too much by individual firm characteristics.

Table 4. Regression results for the Probit, Logit, and Scobit Models

\begin{tabular}{|c|c|c|c|c|c|c|c|c|c|}
\hline & \multicolumn{3}{|c|}{ Probit } & \multicolumn{3}{|c|}{ Logit } & \multicolumn{3}{|c|}{ Scobit } \\
\hline & Coeff. & $\begin{array}{l}\text { Std. } \\
\text { Err. }\end{array}$ & P-value & Coeff. & $\begin{array}{l}\text { Std. } \\
\text { Err. }\end{array}$ & P-value & Coeff. & $\begin{array}{l}\text { Std. } \\
\text { Err. }\end{array}$ & P-value \\
\hline Constant & 6.53 & 1.50 & 0.00 & 11.69 & 0.65 & 0.00 & 6.75 & 1.69 & 0.00 \\
\hline $\begin{array}{l}\text { First-day } \\
\text { turnover ratio }\end{array}$ & -4.28 & 0.93 & 0.00 & -7.65 & 1.66 & 0.00 & -4.45 & 1.04 & 0.00 \\
\hline Price update & 0.28 & 0.19 & 0.03 & 0.35 & 0.19 & 0.00 & 0.16 & 0.12 & 0.16 \\
\hline $\mathrm{P} /$ E ratio & -0.37 & 0.34 & 0.28 & -0.63 & 0.59 & 0.28 & -0.53 & 0.41 & 0.19 \\
\hline $\begin{array}{l}\text { Winning lottery } \\
\text { ratio }\end{array}$ & 0.03 & 0.09 & 0.73 & 0.06 & 0.16 & 0.74 & 0.01 & 0.09 & 0.88 \\
\hline $\begin{array}{l}\text { Dummy (Under- } \\
\text { writer first rank) }\end{array}$ & 0.22 & 0.20 & 0.26 & 0.38 & 0.33 & 0.25 & 0.30 & 0.22 & 0.18 \\
\hline $\begin{array}{l}\text { Stock market } \\
\text { return }\end{array}$ & -5.55 & 1.51 & 0.00 & -9.69 & 2.68 & 0.00 & -7.22 & 2.00 & 0.00 \\
\hline $\begin{array}{l}\text { Stock market } \\
\text { return squared }\end{array}$ & -58.03 & 11.11 & 0.00 & -101.77 & 20.49 & 0.00 & -77.61 & 15.77 & 0.00 \\
\hline $\begin{array}{l}\text { Average initial } \\
\text { return }\end{array}$ & -1.52 & 0.71 & 0.03 & -2.73 & 1.21 & 0.02 & -1.69 & 0.77 & 0.03 \\
\hline Log likelihood & -113.11 & & & -112.78 & & & -111.48 & & \\
\hline $\begin{array}{l}\text { Prob > chi } \\
\text { square }\end{array}$ & & & 0.00 & & & 0.00 & & & 0.000 \\
\hline Pseudo $\mathrm{R}^{2}$ & 0.34 & & & 0.36 & & & & & \\
\hline
\end{tabular}

Results for the logit and scobit models yield results similar to those for the probit model. That is, these models show that turnover ratio, price update, stock market return and average initial return are important factors in explaining the risk of falling prices. Our results are robust across different models.

Our results have important policy implications. Policymakers should slow down the listing approval for IPOs as the market for them is currently unfavourable. In addition, policymakers and underwriters should make an effort to stabilize first-day trading by actively participating 
in the market so as to potentially mitigate the risk of falling prices. In other emerging markets, such as Taiwan, the government explicitly allows underwriting to boost stock prices during the first few days after an IPO (Zeng et al. 2012).

\section{Conclusions}

Based on 281 IPOs from the Growth Enterprise Board (GEB) of the Shenzhen Stock Exchange (SZSE), we investigate factors that explain the probability of the trading price for new issues that will fall below the offering price. Our study covers all IPOs issued since the initiation of the GEB market, that is, October 2009 to December 31, 2011.

We use three probability models (logit, probit and scobit models) for our purpose and for robustness. Our results show that four important factors explain the probability of falling prices for IPOs: first-day turnover ratio, price update, average initial returns of prior IPOs, and general market performance. Another interesting point is to be noted here. We find that the stock market returns have a non-linear effect on the probability, indicating that its effect is particularly important.

Our results have important implications for different market participants. First, policymakers who wish to regulate the IPOs effectively need to understand the underlying forces of the overpricing. In this case, the general market sentiment plays an important role in the overpricing of the IPOs, which does not appear to be strongly related to the firm attributes. As a result, regulators should slow down the IPO approval process when the stock market in general and the IPO market in particular are bearish. Second, the issuing firms and underwriters need to understand the importance of market sentiment when placing the IPOs in order to ensure their success. When market is down, they should try to delay launching IPOs to avoid the risk of falling prices. Underwriters in the Chinese IPO market should make an effort to stabilize trading on the initial day of trading as the high initial-day turnover and returns are shown to be important in reducing this falling risk. Future research should apply our models in other markets to see whether overpricing of IPOs there can be similarly explained and the results across different countries can be compared.

\section{Acknowledgement:}

This study was sponsored by the National Natural Science Foundation of China (No. 71103049 and No. 71031003), the Chinese Distinguished Post-doctoral Fund (2012T50369), the Humanity and Social Science Research Foundation (10YJC790070), the Research Fund for the Doctoral Program of Higher Education (20112302120038) and the New Century Talents (2013 Haifeng Guo) of the Ministry of Education.

\section{References}

Aggarwal, R. 2000. Stabilization activities by underwriters after initial public offerings, Journal of Finance 55(3): 1075-1103. http://dx.doi.org/10.1111/0022-1082.00241

Chan, K.; Wang, J.; Wei, K. 2004. Underpricing and long-term performance of IPOs in China, Journal of Corporate Finance 10(3): 409-430. http://dx.doi.org/10.1016/S0929-1199(03)00023-3 
Chen, G.; Firth, M.; Kim, J. 2004. IPO underpricing in China’s new stock markets, Journal of Multinational Financial Management 14(3): 283-302. http://dx.doi.org/10.1016/j.mulfin.2003.07.007

Chi, J.; Padgett, C. 2005. Short-run underpricing and its characteristics in Chinese initial public offering (IPO) Market, Research in International Business and Finance 19(1): 71-93. http://dx.doi.org/10.1016/j.ribaf.2004.10.004

Chiou, J.; Li, M.; Cheng, L.; Chang, S. 2010. Pricing and allocation mechanisms in underpricing of Chinese IPOs, Chinese Economy 43(1): 93-108. http://dx.doi.org/10.2753/CES1097-1475430105

Cornelli, F.; Ljungqvist, A.; Goldreich, D. 2006. Investor sentiment and pre-IPO markets, Journal of Finance 61(3): 1187-1216. http://dx.doi.org/10.1111/j.1540-6261.2006.00870.x

Derrien, F. 2005. IPO pricing in "Hot" market conditions: who leaves money on the table?, Journal of Finance 60(1): 487-521. http://dx.doi.org/10.1111/j.1540-6261.2005.00736.x

Dong, X.; Pandey, M. 2012. Gender and labor retrenchment in Chinese state owned enterprises: investigation using firm-level panel data, China Economic Review 23(2): 385-395. http://dx.doi.org/10.1016/j.chieco.2012.02.006

Ellis, K.; Michaely, R.; O'Hara, M., 2000. When the underwriter is the market maker: an examination of trading in the IPO aftermarket, Journal of Finance 55(3): 1039-1074. http://dx.doi.org/10.1111/0022-1082.00240

Fung, H.; Kummer, D.; Shen, J. 2006. China's privatization reforms, Chinese Economy 39(2): 5-25. http://dx.doi.org/10.2753/CES1097-1475390202

Fung, H.; Liu, W.; Yau, J. 2007. Financing alternatives for Chinese small and medium enterprises: the case for a small and medium enterprise stock market, China and World Economy 15(1): 26-42. http://dx.doi.org/10.1111/j.1749-124X.2007.00053.x

Guariglia, A.; Liu, X.; Song, L. 2011. Internal finance and growth: micro econometric evidence on Chinese firms, Journal of Development Economics 96(1): 79-94. http://dx.doi.org/10.1016/j.jdeveco.2010.07.003

Guo, H.; Fung, H. 2011. Growth enterprise board initial public offerings: characteristics, volatility and the initial-day performance, China and World Economy 19(1): 106-121. http://dx.doi.org/10.1111/j.1749-124X.2011.01229.x

Guo, H.; Brooks, R.; Fung, H. 2011. Underpricing of Chinese initial public offerings, Chinese Economy 44(5): 72-85. http://dx.doi.org/10.2753/CES1097-1475440504

Guo, H.; Brooks, R.; Shami, R. 2010. Detecting hot and cold cycles using Markov regime switching models - evidence from the Chinese A-Share IPO market, International Review of Economics and Finance 19(2): 196-210. http://dx.doi.org/10.1016/j.iref.2009.10.002

Kutsuna, K.; Smith, J.; Smith, R. 2009. Public information, IPO price formation, and long-run returns: Japanese evidence, Journal of Finance 64(1): 505-546. http://dx.doi.org/10.1111/j.1540-6261.2008.01440.x

Lewellen, K. 2006. Risk, reputation and IPO price support, Journal of Finance 61(2): 613-653. http://dx.doi.org/10.1111/j.1540-6261.2006.00850.x

Li, A.; McMahon, D. 2012. In China, debate on IPO disclosure, Wall Street Journal [online], [cited 8 March 2012]. Available from Internet: http://online.wsj.com/article/SB10001424052970204781804 577268340380632640.html

Li, A. 2012. China weighs new equity exchange, Wall Street Journal [online], [cited 23 March 2012]. Available from Internet: http://online.wsj.com/article/SB10001424052702304636404577299270134 481952.html?mod=WSJ_hp_LEFTWhatsNewsCollection/

Li, A.; Hong, S. 2012. China may expand OTC trading trial for unlisted firms, Wall Street Journal [online], [cited 19 July 2012]. Available from Internet: http://online.wsj.com/article/SB100008723963904443 30904577536050703044094.html

Liu, Q.; Tian, G.; Wang, X. 2011. The effect of ownership structure on leverage decision: new evidence from Chinese listed firms, Journal of the Asia Pacific Economy 16(2): 254-276.

http://dx.doi.org/10.1080/13547860.2011.564755 
Loughran, T.; Ritter, J. 2004. Why has IPO underpricing changed over time? Financial Management 33: 5-37.

Lowry, M.; Officer, M.; Schwert, G. 2010. The variability of IPO initial returns, Journal of Finance 65(2): 425-465. http://dx.doi.org/10.1111/j.1540-6261.2009.01540.x

Megginson, W.; Weiss, K. 1991. Venture capitalist certification in initial public offerings, Journal of Finance 46(3): 879-903. http://dx.doi.org/10.1111/j.1540-6261.1991.tb03770.x

Milana, C.; Wu, H. 2012. Growth, institutions, and entrepreneurial finance in China: a survey, Strategic Change 21(3-4): 83-106. http://dx.doi.org/10.1002/jsc.1897

Nagler, L. 1994. Scobit: an alternative estimator to logit and probit, American Journal of Political Science 38: 230-255. http://dx.doi.org/10.2307/2111343

Pilinkus, D. 2010. Macroecnomic indicators and their impact on stock market performance in the short and long run: the case of the Baltic states, Technological and Economic Development of Economy 16(2): 291-304. http://dx.doi.org/10.3846/tede.2010.19

Wong, C.; Govindaraju, C. 2012. Technology stock and economic performance of government-linked companies: the case of Malaysia, Technological and Economic Development of Economy 18(2): 248-261. http://dx.doi.org/10.3846/20294913.2012.688313

Zandi, F.; Tavana, M.; O'Connor, A. 2012. A strategic cooperative game-theoretic model for market segmentation with application to application to banking in emerging economies, Technological and Economic Development of Economy 18(3): 389-423. http://dx.doi.org/10.3846/20294913.2012.688072

Zeng, R.; Zeng, S.; Xie, X.; Tam, Ch.; Wan, T. 2012. What motives firms from emerging economics to go internationalization, Technological and Economic Development of Economy 18(2): 280-298. http://dx.doi.org/10.3846/20294913.2012.677588

Zhang, J.; Wang, L.; Wang, S. 2012. Financial development and economic growth: Recent evidence from China, Journal of Comparative Economics 40(3): 393-412. http://dx.doi.org/10.1016/j.jce.2012.01.001

Zhao, X.; Sun Y. 2012. Performance change and its influence factors in IPO- an empirical study on China growth enterprise market, Advance in Applied Economics and Finance 4: 202-206.

Haifeng GUO is an Associate Professor at the Department of Applied Economics, School of management, Harbin Institute of Technology, China. She got her PhD degree in Economics in Monash University, Australia. Her research area includes initial public offerings and monetary policy, etc.

Tienan WANG is a Professor at the Department of Business Administration, School of Management, Harbin Institute of Technology, China. His research area is managerial economics, which include investing strategy, stock market and supply chain management.

Yijun LI is a Professor at the Department of Management Science and Engineering, School of Management, Harbin Institute of Technology, China. He is also the Deputy Head of the Management Division in National Natural Science Foundation of China. His research area includes information system, economics in management, etc.

Hunggay FUNG is a Professor in College of Business Administration, University of Missouri-St. Louis, USA. His research area includes stock market, Chinese economy and monetary policies, etc. 